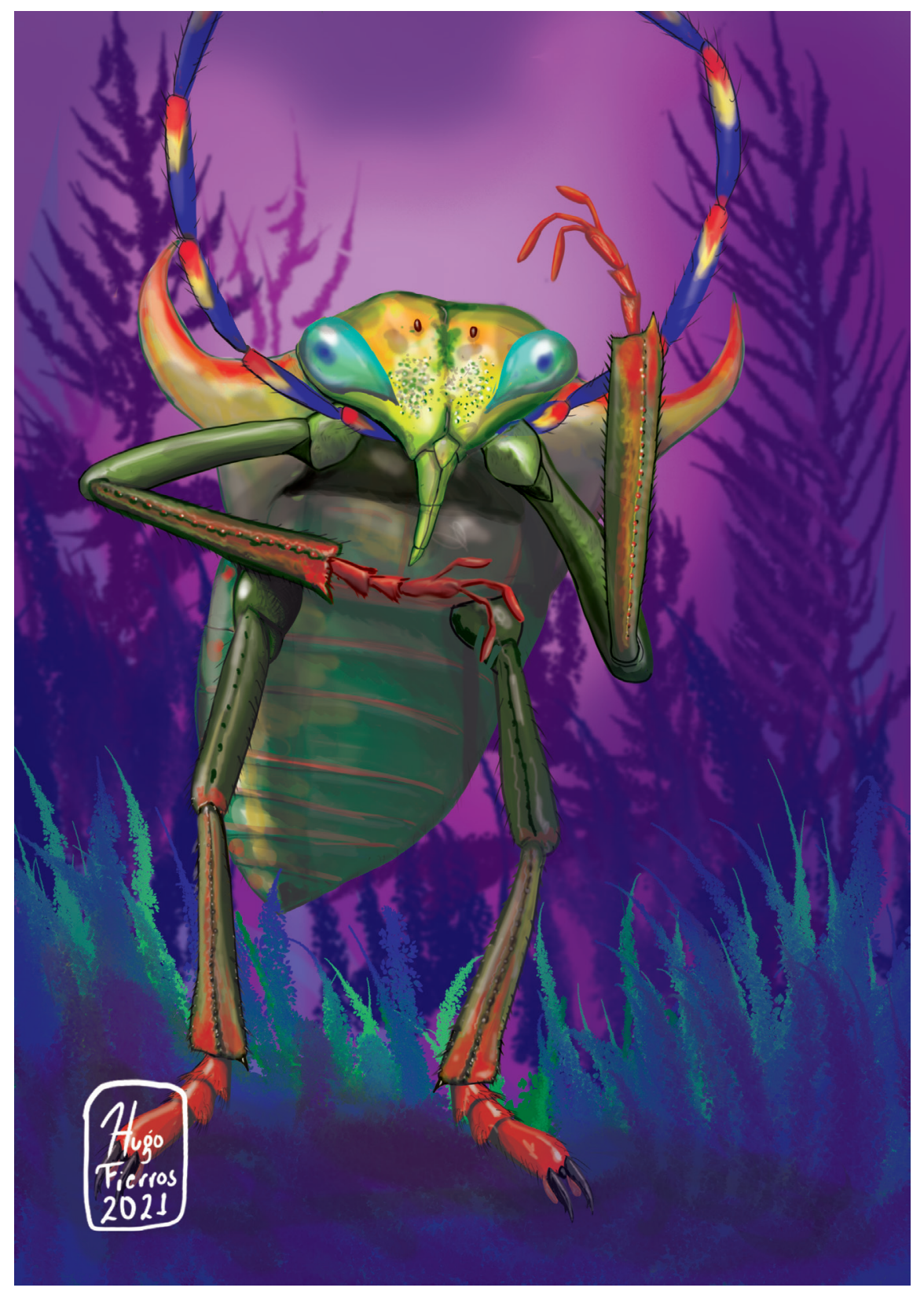

Dugesiana, Año 29, No. 1, (enero-junio, primer semestre 2022), es una publicación semestral, editada por la Universidad de Guadalajara, a través del Centro de Estudios en Zoología, por el Centro Universitario de Ciencias Biológicas y Agropecuarias. Camino Ramón Padilla Sánchez \# 2100, Nextipac, Zapopan, Jalisco, Tel. 37771150 ext. 33218, http://148.202.248.171/dugesiana/index.php/DUG/index, glenusmx@gmail.com. Editor responsable: José Luis Navarrete-Heredia. Reserva de Derechos al Uso Exclusivo 04-2009-062310115100-203, ISSN: 20079133, otorgados por el Instituto Nacional del Derecho de Autor. Responsable de la última actualización de este número: José Luis Navarrete-Heredia, Editor y Ana Laura González-Hernández, Asistente Editorial. Fecha de la última modificación 1 de enero de 2022, con un tiraje de un ejemplar.

Las opiniones expresadas por los autores no necesariamente reflejan la postura del editor de la publicación.

Queda estrictamente prohibida la reproducción total o parcial de los contenidos e imágenes de la publicación sin previa autorización de la Universidad de Guadalajara. 


\title{
New locality records for ants in the coffee zone of Cundinamarca, Colombia
}

\section{Nuevos registros locales de hormigas en la zona cafetalera de Cundinamarca, Colombia}

\author{
Ricardo Martínez Gamba \\ Universidad Pedagógica Nacional, Departamento de Biología, Grupo de investigación CASCADA. \\ Calle 72 -11-86 oficina B325, Bogotá, Colombia rmartinezg@pedagogica.edu.co
}

\begin{abstract}
Shade coffee plantations harbor a great diversity of ants that in some cases have not been recorded. Therefore, it is important the information of their distribution both locally and regionally, five new records for the coffee region of Cundinamarca are related here, four species for the subfamily Myrmicinae with: Protalaridris armata, Nesomyrmex pittieri, Cyphomyrmex peltatus, Strumigenys pariensis and for the subfamily Proceratinae the species Proceratium colombicum.
\end{abstract}

Keywords: Biodiversity, Formicidae, neotropical region, Quipile, shade coffee

\section{RESUMEN}

Los cafetales de sombrio albergan una gran diversidad de hormigas que en algunos casos no han sido registradas. Por lo tanto es importante la información de su distribución tanto local como regional, cinco nuevos registros para la región cafetera de Cundinamarca se relacionan aquí, cuatro especies para la subfamilia Myrmicinae con: Protalaridris armata, Nesomyrmex pittieri, Cyphomyrmex peltatus, Strumigenys pariensis y para la subfamilia Proceratinae la especie Proceratium colombicum.

Palabras clave: Biodiversidad, Formicidae, neotropical, Quipile, Café de sombra.

The coffee agroecosystem in Colombia is characterized by a high diversity of fauna and flora, located in the equatorial strip of the Neotropical region in the north of South America (Constantino 2020). This is part of the tropical Andes considered a globally critical point (hotspot) (Myers et al. 2000). The presence of shade in coffee plantations can promote ecological functions because they attract associated fauna of great importance such as insects (Manson et al. 2008). Due to the close relationship between plants and insects, the high percentage of plant endemism in the tropical Andes (about half of the species) suggests a high level of insect diversity and endemism (Larsen et al. 2011). Among these insect groups, ants present a high diversity in Colombia with an estimated 1100 species compared to the 3300 species reported in the Neotropical region (Guerrero et al. 2018). Highlighting, that in these agroecosystems even though there is strong pressure to increase their productivity or transform to other land uses (Rojas et al. 2012). They continue to maintain a great richness of ants (Cepeda et al. 2014, Martínez 2018). Where they fulfill important functions as biological predators of the coffee berry borer (Escobar et al. 2020). They can act as bioindicators (Alonso y Agosti 2000). They improve soil composition (Philpott et al. 2010). And regulate the population of arthropods (Gallego-Ropero y Armbrecht 2005). However, the diversity patterns of ants in coffee landscapes remain poorly understood (Escobar et al. 2020). Therefore, there is the possibility of finding new local and regional records, motivating us to continue with this type of work in coffee plantations in Colombia.

\section{MATERIAL AND METHODS}

The specimens were collected in December 2016 and 2017 in a pitfall trap and manual collect in a coffee farm in Quipile, Cundinamarca (04.46.13.3N, 074.32.06.8W), which is located $83 \mathrm{~km}$ west of Bogotá city, Colombia (Fig. 1). It has an altitude between 1599 and 1702 m.n.s.m, also presents a temperature from $16^{\circ} \mathrm{C}$ to $18^{\circ} \mathrm{C}$ and rainfall between 1,000 and 2,000 $\mathrm{mm}$. This place is part of the Premontane damp forest (Rodríguez et al. 2006).

The digital images were generated with a Nikon AZ100M multipurpose zoom microscope software with Nikon elements a high-resolution digital camera (Type 
DS-U3) and a Leica MC170 HD camera with a Leica 10450528 adapters on a Leica M205 A microscope using a $1 \mathrm{x}$ objective. Other digital images were taken from AntWeb (2021). The keys and the diagnosis developed in this work based on the following documents: Lattke et al. (2018) for Protalaridris, Kempf (1959) for Nesomyrmex, Kempf (1966) for Cyphomyrmex, Lattke and Goitía (1997) for Strumigenys and Baroni Urbani and de Andrade (2003) for Proceratium.

\section{RESULTS}

Subfamily Myrmicinae:

Protalaridris armata Brown, 1980

Material examined: COLOMBIA, Cundinamarca. Quipile, Vereda Guadalupe Alto, Finca San Miguel. Shade coffee plantation. $04.46 .21 .7 \mathrm{~N}, \quad 074.32 .06 .3 \mathrm{~W} .1722 \mathrm{~m}$. Pitfall trap.20-December-2016. Martinez.R.1 Worker. ICN100266.Figs, 2A, 2B.

Comments: Only two species are known in Colombia, one recently described Protalaridris arhuaca Guerrero, Lattke \& Alpert, 2018 in the Sierra Nevada de Santa Marta and $P$. armata, which is known in Panama, Ecuador, and Venezuela. In Colombia, it known in Chocó and Nariño (Fernández et al. 2019).

Nesomyrmex pittieri (Forel, 1899)

Material examined: COLOMBIA, Cundinamarca. Quipile, Vereda Guadalupe Alto, Finca San Miguel, 04.46.20.6N， 074.32.05.7W.1710m. Shade coffee plantation. Manual capture found in tree trunk Citrus aurantium L, 1753. 19-April-2017. Martinez. R .2 workers. ICN100267. Figs, 3A, 3B.

Comments: Known from México, Costa Rica, Nicaragua Panamá (Kempf 1959). In Colombia has been recorded in Cauca (Chacón de Ulloa et al. 2014), and Caldas (Fernández et al. 1996).

\section{Cyphomyrmex peltatus Kempf, 1966}

Material examined: COLOMBIA, Cundinamarca. Quipile, Vereda Guadalupe Alto, Finca Los Naranjitos, 04.46.10.7N ,07432.06.3W.1599. Shade coffee plantation. Pitfall trap. 22-December-2016. Martinez. R .1 worker. ICN100268. Figs, 4A, 4B.

Comments: This species is very similar to Cyphomyrmex rimosus (Spinola, 1851), but these are its differences: no middle pronotal tubercles, a pentagonal impression in the mesonotum, delimited by the four lower welts, postpetiolar mediodorsal always deeper, thin hairs, recovered, not scaly (Kempf 1966).

Known from Costa Rica to Brazil (Rio Grande do Sul). In Colombia: Moni-fue, Leticia, Amazonas (Perez et al. 2009). Huila, Putumayo, Quindío, and Vichada (Fernandez et al. 2019).

Strumigenys pariensis Lattke and Goitía, 1997

Material examined: COLOMBIA, Cundinamarca.
Quipile, Vereda Guadalupe Alto, Finca los Naranjitos, 04.46.12.7N， 074.32.05. 0W.1585m. Shade coffee plantation. Manual capture around the lower part of the trunk of C. aurantium. Pitfall trap. 14-November-2016. Martinez. R .2 workers. ICN100269. Figs, 5A, 5B.

Comments: Although confused with S. elongata, the basal ribbing of the first tergus of the gaster also differs, and it does not extend after the first pair of medium erect hairs (Lattke and Goitía 1997).

This species is known from México, Costa Rica, Honduras, Nicaragua to Venezuela. In Colombia is known without a specific locality (Fernandez et al. 2019).

Subfamily Proceratinae:

Proceratium colombicum De Andrade, 2003

Material examined: COLOMBIA, Cundinamarca. Quipile, Vereda Guadalupe Alto, Finca los Naranjitos, 04.46.13.3N, 074.32.06.8W .1593m. Shade coffe plantation. Pitfall trap. 22-December-2016 Martinez. R .1 queen. NC5SL. Figs, 6A, 6B.

Comments: This is the smallest species of the micrommata clade, is endemic to Colombia; it is known only for the department of Nariño. (Baroni Urbani and de Andrade 2003).

\section{CONCLUSIONS}

The coffee plantations of the coffee-growing area of Cundinamarca have the potential as a habitat for ant diversity, therefore it is important to conserve and maintain this type of agroecosystems motivating studies to report new records and possibly new species.

\section{ACKNOWLEDGMENT:}

To the institute ENTOMA and ICN-UNAL for the photographs of Proceratium and Protalaridris, to Rodolfo Probst and Maria Camila Tocora for the corroboration and determination of the ant's species.

\section{LITERATURE CITED}

Alonso, L.E. and D. Agosti. 2000. Biodiversity studies, monitoring, and ants: an overview. (pp. 1-8) In: D. Agosti, J.D. Majer, L.E. Alonso y T.R. Schultz (Eds.). Ants: Standard methods for measuring and monitoring biodiversity. Smithsonian Institution Press, Washington D.C.

ANTWEB. 2021. versión 8.60. California Academy of Science. https://www.antweb.org/ [Review date: 16 April 2021].

Baroni Urbani, C. and M.L. De Andrade. 2003. The ant genus Proceratium in the extant and fossil record (Hymenoptera: Formicidae). Museo Regionale di Scienze Naturali, Monografie, 36: 1-492.

Cepeda-Valencia, J., L. Pérez-Pedraza and F. Fernández. c2014. Hormigas de hojarasca asociadas a fragmentos de bosque y cafetales de la zona cafetera de Cundinamarca, 171 registros. [Last accessed: 28- 
02-2021]. http://ipt.sibcolombia.net/sib/resource.do? $\mathrm{r}=$ unal-002

Chacón de Ulloa, P., S. Valdes-Rodriguez., A. HurtadoGiraldo and C. M. Pimienta.2014. Arboreal ants of Gorgona National Park (Pacific of Colombia). Revista de Biología Tropical, 62(1): 277-287.

Constantino, L.M. 2020. El control biológico natural. (pp. 36-67). En: Benavides-Machado, P y C.E. Góngora (Eds.). El Control Natural de Insectos en el Ecosistema Cafetero Colombiano Cenicafé. Caldas, Colombia. https://doi.org/10.38141/10791/0001_3

Escobar-Ramírez, S., T. Tscharntke., I. Armbrecht., W. Torres. \& I. Grass.2020. Decrease in $\beta$-diversity, but not in $\alpha$-diversity, of ants in intensively managed coffee plantations. Insect Conservation and Diversity, 13(5):445-455.

Gallego-Ropero, M.C. y I. Armbrecht. 2005. Depredation por hormigas sobre la broca del cafe Hypothenemus hampei (Curculionidae: Scolytinae) en cafetales cultivados bajo dos niveles de sombra en Colombia. Manejo Integrado de Plagas y Agroecología ,76:32-40.

Guerrero, R.J., F. Fernández., M.E. Escárraga., L.F. Pérez-Pedraza., F. Serna., W.P. Mackay., Sandoval., V. Vergara., D. Suárez., E.I. García., A. Sánchez., A.D. Meneses., M.C. Tocora and J. Sosa-Calvo.2018. New records of myrmicine ants (Hymenoptera: Formicidae) for Colombia. Revista Colombiana de Entomología, 44(2): 238-259. doi: https://doi.org/10.25100/socolen. v44i2.7115

Fernández, F., E.E. Palacio., W.P. MacKay y E.S. MacKay.1996. Introducción al estudio de las hormigas (Hymenoptera: Formicidae) de Colombia. (pp. 34941). En: Andrade MG, Amat García G, Fernández F, (Eds). Insectos de Colombia. Estudios escogidos. Bogotá: Academia Colombiana de Ciencias Exactas, Físicas y Naturales. Bogotá D.C.

Fernández, F., R.J. Guerrero \& T. Delsinne. (Eds.). 2019. Hormigas de Colombia. Primera edición. Bogotá. Universidad Nacional de Colombia. Facultad de Ciencias. Instituto de Ciencias Naturales, Bogotá D.C.

Kempf, W.W. 1959. A synopsis of the New World species belonging to the Nesomyrmex-group of the ant genus Leptothorax Mayr (Hymenoptera: Formicidae). Studia Entomologica, (n.s.) 2: 391-432.

Recibido: 8 de junio 2021

Aceptado: 12 de noviembre 2021
Kempf, W.W. 1966 [1965]. A revision of the Neotropical fungus-growing ants of the genus Cyphomyrmex Mayr. Part II: Group of rimosus (Spinola) (Hymenoptera: Formicidae). Studia Entomologica, 8: 161-200.

Larsen, T. H., F. Escobar and I. Armbrecht. 2011. Insects of the tropical Andes: diversity patterns, processes and global change, (pp. 228-244). In Herzog, S. K., R. Martínez, P. M. Jorgensen, and H. Tiessen (Eds.). Climate change and biodiversity in the Andes. MacArthur Foundation, Chigago, USA.

Lattke, J.E., T. Delsinne., G. D. Alpert. and R.J. Guerrero. 2018. Ants of the genus Protalaridris (Hymenoptera: Formicidae), more than just deadly mandibles. European Journal of Entomology 115: 268-295.doi: 10.14411/ eje. 2018.027

Lattke, J.E., W. Goitía. 1997. El género Strumigenys (Hymenoptera: Formicidae) en Venezuela. Caldasia 19: 367-396.

Myers, N., R. A. Mittermeier., C. G. Mittermeier., G.A.B. da Fonseca and J. Kent. 2000. Biodiversity hotspots for conservation priorities. Nature 403:853-858.

Manson, R.H., V. Hernández-Ortiz., S. Gallina., K. Mehltreter. (Eds) 2008.Agroecosistemas cafetaleros de Veracruz Biodiversidad, Manejo y Conservación. México. Instituto de Ecología A.C. (INECOL) e Instituto Nacional de Ecología (INE-SEMARNAT). México D.C.

Martínez, G. R. 2018. Mirmecofauna asociada a cafetales bajo sombra en Quipile, Cundinamarca, Colombia. Acta Agronómica,67(4).461-470.

Pérez, L.G., G.A. Pérez., C. Echeverri-Rubiano., A.F. Sánchez., J. Durán y L.M Pedraza. (2009). Riqueza de hormigas (Hymenoptera: Formicidae) en Várzea y Bosque de Tierra Firme de la región amazónica colombiana. Boletín de la Sociedad Entomológica Aragonesa, 45: 477-483.

Philpott, S.M., I. Perfecto, I. Armbrecht y C.L. Parr. 2010. Effects of disturbance and habitat transformation on ant diversity and function. (pp. 137-156) In: L. Lach, C. Parr y K.L. Abbott (Eds.) Ant ecology. Oxford University Press, Oxford, UK.

Rojas, S.A., K.U Hartman and R.M Almonacid. 2012. El impacto de la producción de café sobre la biodiversidad, la transformación del paisaje y las especies exóticas invasoras. Ambiente y Desarrollo 16(30):93-104.

Rodríguez, N., D. Armenteras., M. Morales y M. Romero.2006. Ecosistemas de los Andes colombianos. Bogotá, Colombia Segunda edición. Instituto de Investigación de Recursos Biológicos Alexander Von Humboldt. 


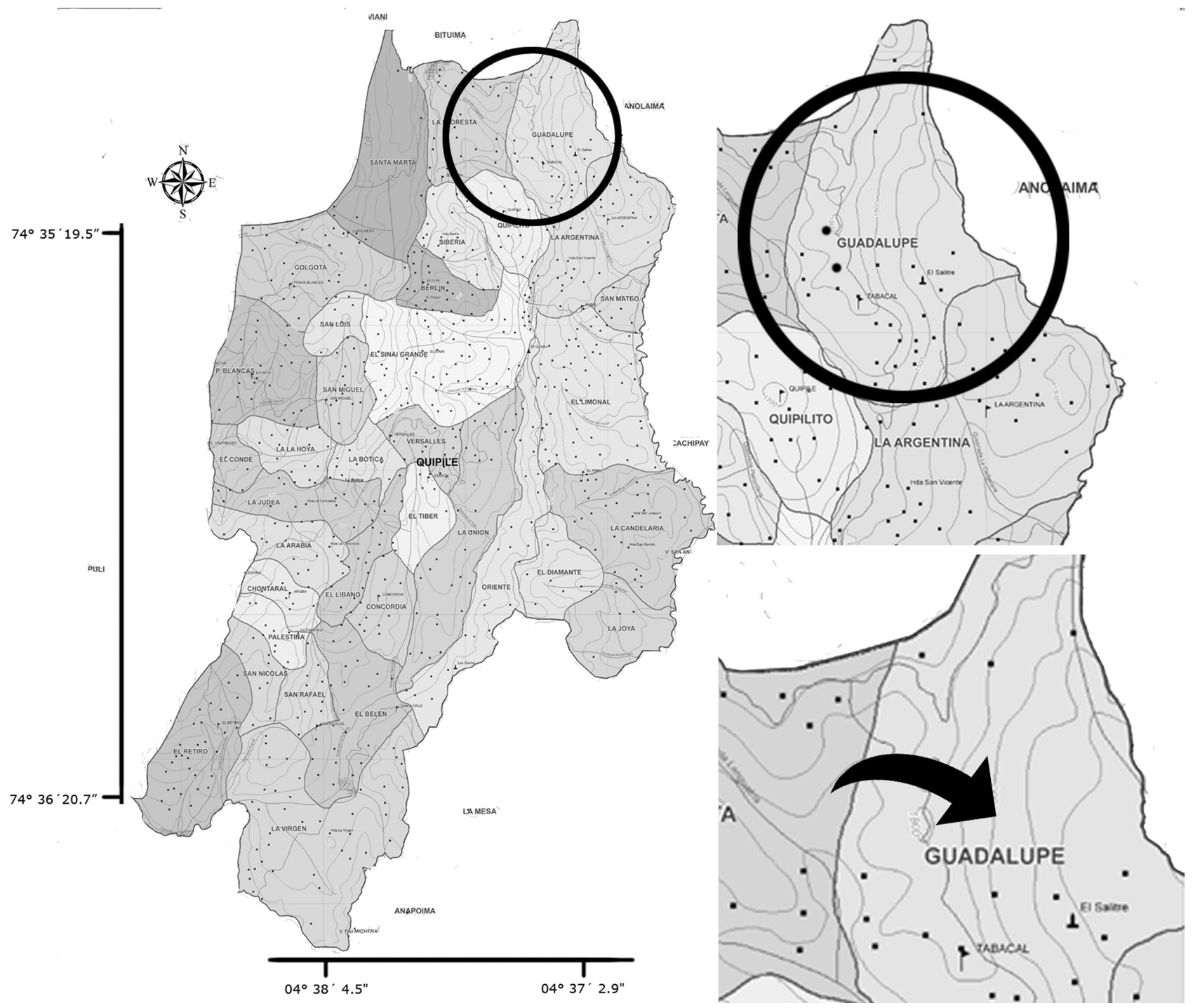

Figure 1. Location of the farms studied on the upper village Guadalupe in the municipality of Quipile (Cundinamarca, Colombia). 


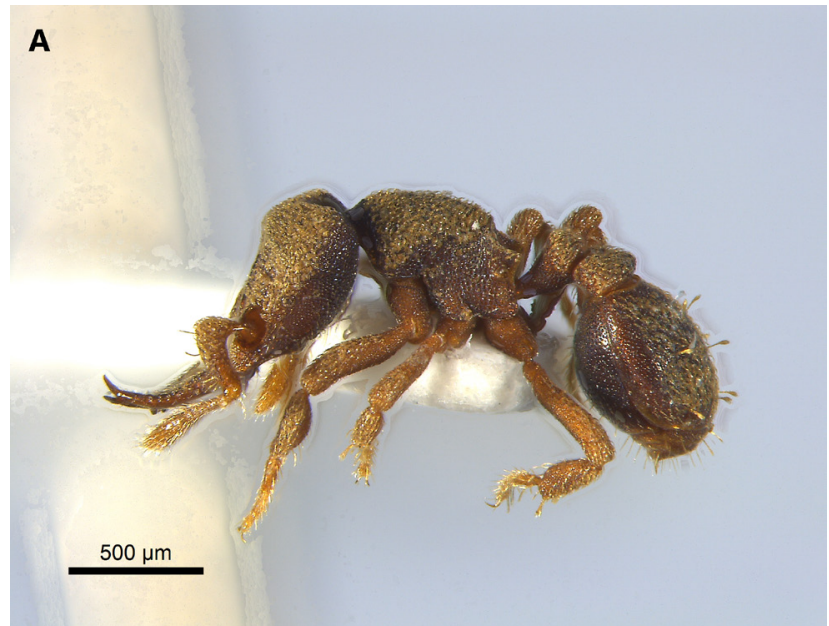

B

Figure 2. Body profile (A) and head in full-face view (B) of the Protalaridris armata worker. Imagen was taken by Camila Tocora ICN.
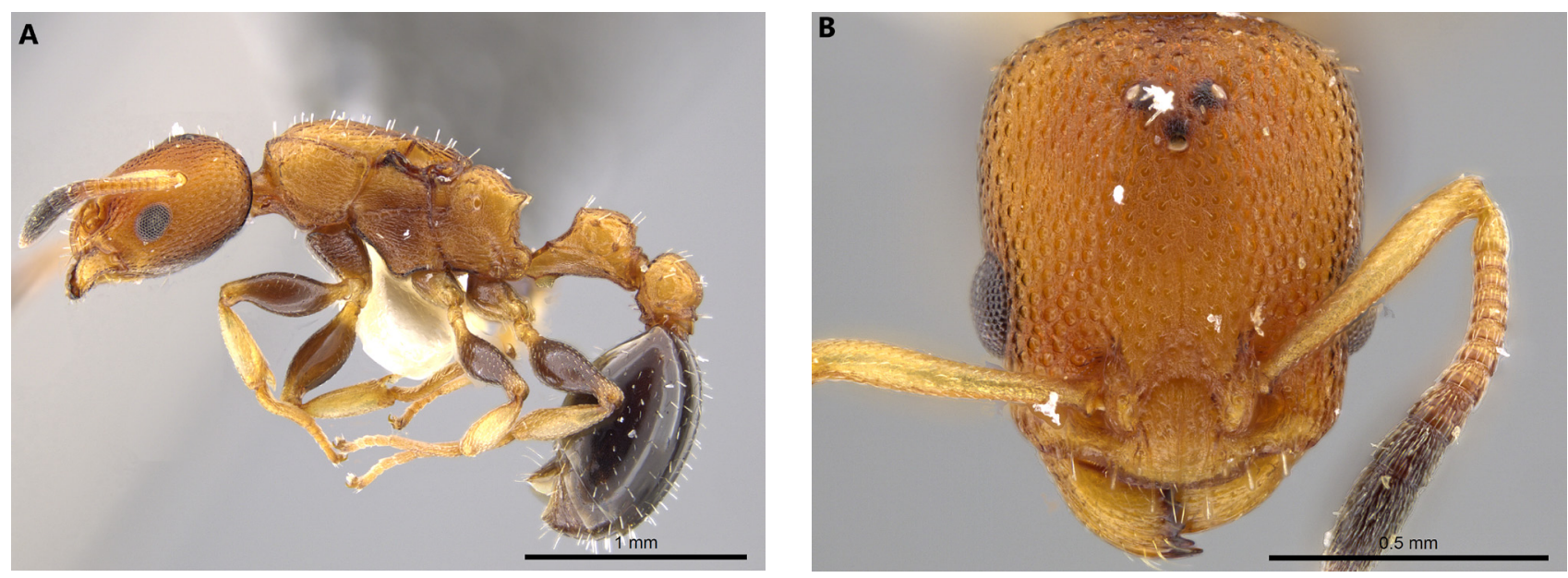

Figure 3. Body profile (A) and head in full-face view (B) of the Nesomyrmex pittieri worker. (INBIO CRI01275159). Image by M.pierce, from www.antweb.org).
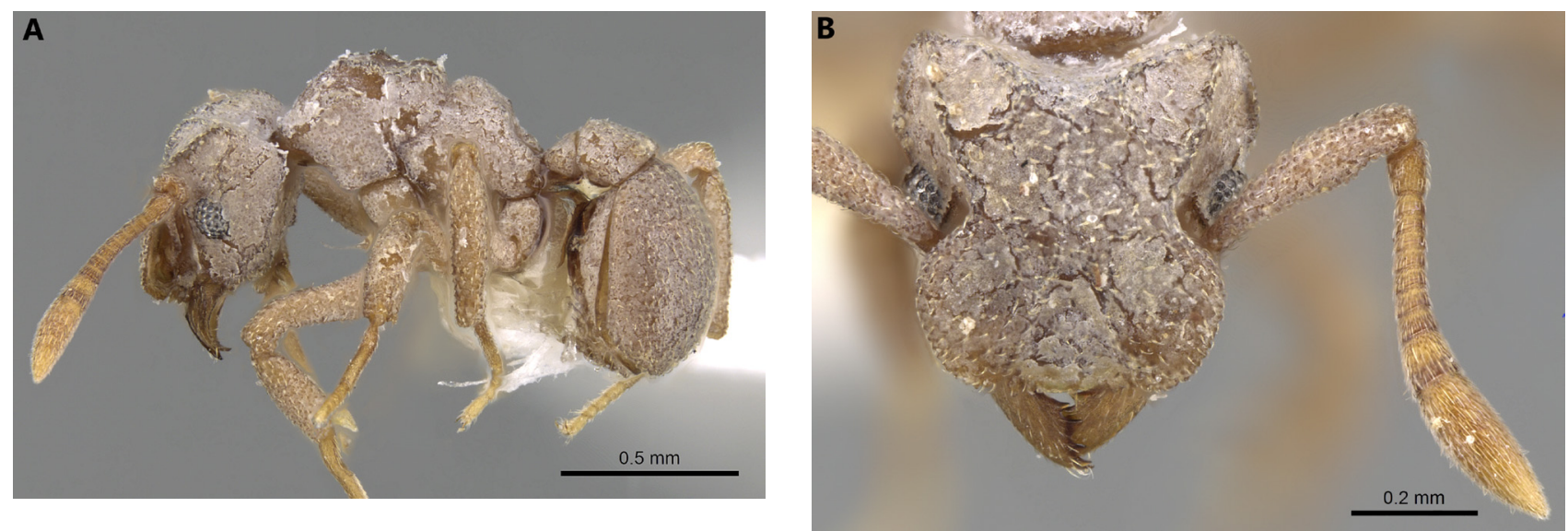

Figure 4. Body profile (A) and head in full-face view (B) of the Cyphomyrmex peltatus worker. (CASENT 0281766). Image by Shannon Harman, from www.antweb.org. 

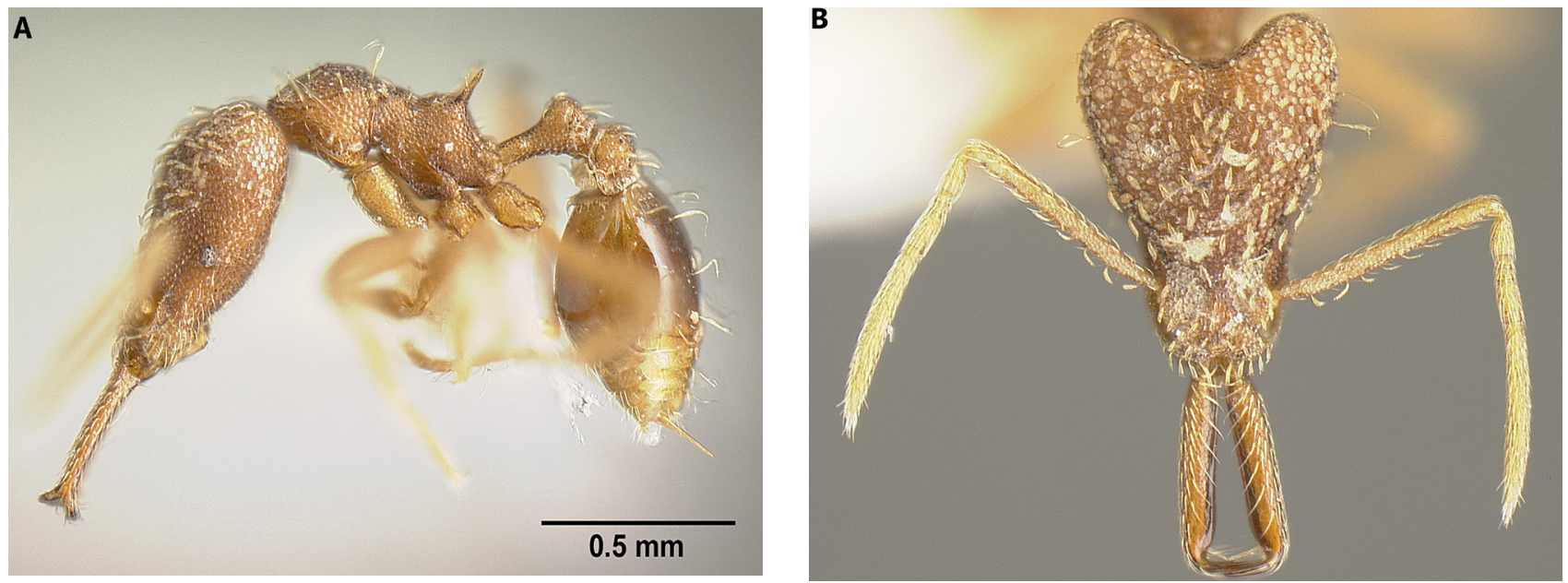

Figure 5. Body profile (A) and head in full-face view (B) of the Strumigenys pariensis worker. (INBIOCRI001283773). Image by D.J Cox, from www.antweb.org).

A

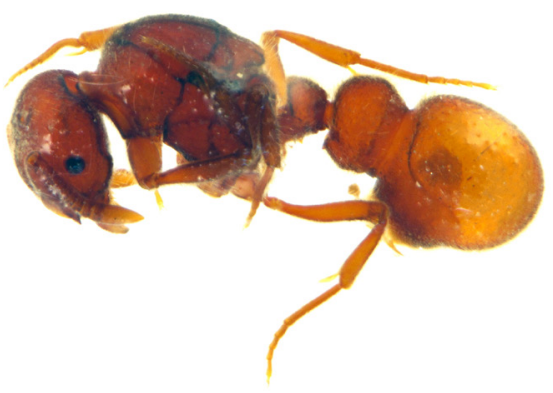

B

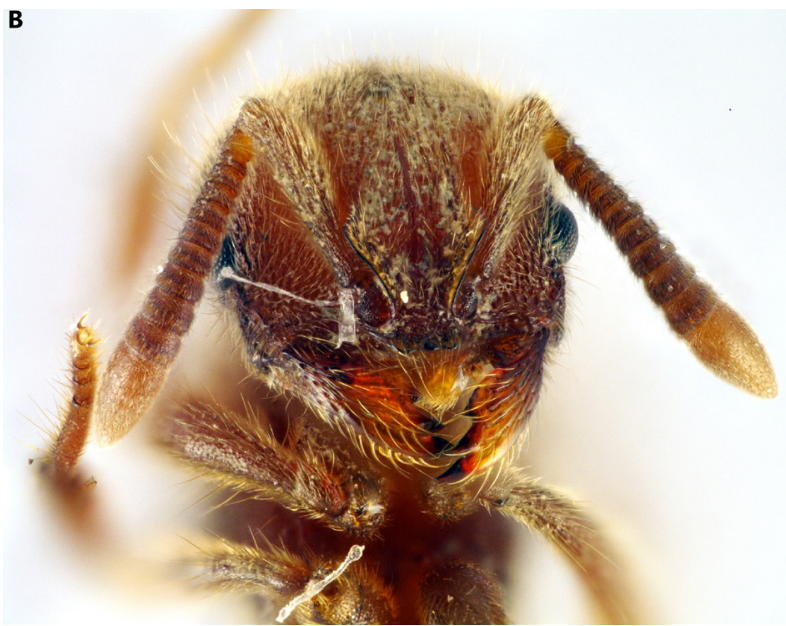

Figure 6. Body profile (A) and head in full-face view (B) of the Proceratium colombicum queen. Imagen was taken by Instituto ENTOMA. 